\title{
Tinnitus Retraining Therapy の調整方法と有効性の評価
}

\author{
荒井 真木, 岩崎 聡, 林 理佐子, 橋本 泰幸 \\ 名倉三津佳, 武林 悟, 水田 邦博, 峯田 周幸 \\ 浜松医科大学耳鼻咽喉科学教室
}

\begin{abstract}
要旨：内服治療等により効果のみられなかった耳鳴患者26名に対し，TCI（Tinnitus Control Instrument）を使用した TRT (Tinnitus Retraining Therapy) 療法を行った。そのう ち 6 名は 2 週から 3 力月で治療の中止を希望した。今回は 6 力月以上治療を継続できた 20 名を対象とした。1 カ月に 1 回 TCIのノイズの種類と大きさの調整を行った。55\%がスピ 一チノイズを選択した。最初の 3 カ月前後に調整条件の変動が見られた。TCIの自覚的治 療効果評価法では $55 \%$ 方有効，25\%がやや有効，20\%が不変，悪化は $0 \%$ あ゙り，有効率 は80\%であった。平均聴力レベルが21〜40dB の群では70\%が有効と答えた。選択したノイ ズと自覚的評価とは関係が見られなかった。耳鳴の大きさと気になり方は治療開始後 3 〜 4 カ月で有効群において改善が認められた。しかし，ラウドネスバランス検查による耳鳴 ラウドネスは有効群でも改善は見られなかった。
\end{abstract}

$$
\text { ーキーワードー }
$$

耳鳴順応療法，ノイズジェネレータ，自覚的評価，ラウドネスバランス検査

\section{はじめに}

耳鳴の治療には内服療法, キシロカイン静注・点 滴療法, 鼓室内薬物注入療法マスキング療法から理 学療法まで多岐にわたる。しかし, その効果は一時 的であり, 治療目的も耳鳴の大きさを軽滅させるこ とにターゲットが向けられている。最近新しい耳鳴 の治療法として Jastreboff ${ }^{1)}$ によって提唱された TRT (Tinnitus Retraining Therapy) 療法があり，70〜90

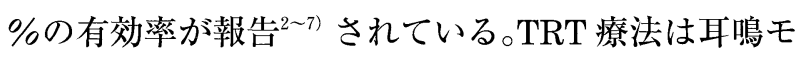
デルを説明する指向性カウンセリングと TCI（Tinnitus Control Instrument) という耳掛け式のノイズ ジェネレーターの装着による治療からなる。マスキ ング療法のように雑音で耳鳴を打ち消すのではなく, ある程度の雑音を聞かせることで耳鳴を意識させな い, 鳴っていても不快と感じないようにする, いわ ゆる順応療法であり，これまでの耳鳴治療法の概念 とは異なるものである。しかし, 我が国ではその有 効性の評価の報告 ${ }^{8)}$ は少ない。今回我々は 6 力月 TRT
療法が継続できた者を対象に, 6 力月間の TRT 療法 後の自覚的評価と連日耳鳴の大きさや気になり方に 対する自覚的評価の平均スコアを比較し, TRT 療法 の有効性とその背景について検討した。また，1力 月ごとに TCI の調整を行う事で, TCI の治療音と音 量の変化についてと TRT 療法の有效性について検討 を加えた。

\section{対象と方法}

3 力月以上内服その他の耳鳴に対する治療を行っ ても改善しなかった耳鳴患者26名に対し浜松医科大 学耳鼻咽喉科耳鳴外来にて TRT 療法を試み, 6 力月 治療が継続できた20例を対象とした。対象者20名(男 性12名, 女性 8 名）の年齢は 25 歳 74歳, 平均年齢 54.8歳であった。耳鳴期間は 4 力月〜20年(平均 7.7 年), 一側耳鳴が 12 名, 両側耳鳴が 8 名であり, 雨側 耳鳴に対してはより耳鳴が大きく自覚する側に TCI を装着した。TCI 装着耳に扮ける 4 分法平均聴力レ ベルが20dB 以下は 3 例, 21 から $40 \mathrm{~dB}$ は10例, $41 \mathrm{~dB}$ 


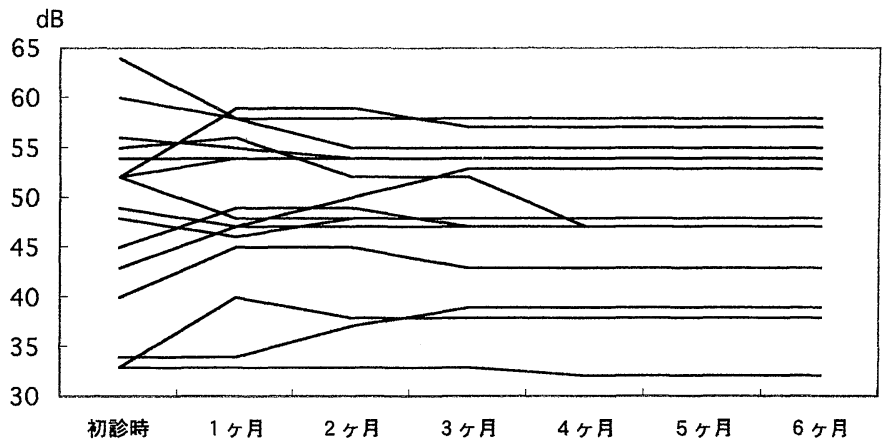

図 1 個々の症例における TCIノイズの大きさ変化

以上は 7 例であり, 平均聴力レベルの平均は $38.5 \mathrm{~dB}$ であった。正常聴力の 3 名を除いた 17 名の聴力型は 高音漸傾型が 13 例，水平型が 4 例であり，難聴，耳 鳴の原因としては老人性難聴と思われるものが 8 例, 突発性難聴が 3 例，外リンパ瘦が 1 例，メニエール 病が 1 例，騒音性難聴が 2 例，慢性中耳炎が 1 例， 遺伝性難聴が 1 例，無難聴耳鳴が 3 例であった。ま た耳鳴のピッチマッチ検查では $8 \mathrm{kHz}$ が11例, $6 \mathrm{kHz}$ が 2 例， $4 \mathrm{kHz}$ が 3 例， $3 \mathrm{kHz} ， 2 \mathrm{kHz} ， 1.5 \mathrm{kHz}$, $125 \mathrm{~Hz}$ がそれぞれ 1 例ずつ，耳鳴のラウドネスバラ ンス検查では $5 \mathrm{~dB}$ 以下が 12 例， $6 \sim 10 \mathrm{~dB}$ が 5 例， $11 \mathrm{~dB}$ 以上が 3 例であった。

治療方法は，専任の担当耳鼻科医が耳鳴と治療法 の説明を含めた約30分のカウンセリングを施行後， 防音室内で TCI の調整を行った。TCI の調整は 1 力 月に 1 度施行し，その度にホワイトノイズ，ピンク ノイズ，スピーチノイズすべてを聞かせた後，より 好みに近いノイズを選択してもらった。ノイズの大 きさはノイズが聞こえ出す音圧とノイズにより耳鳴 が消失する音圧の中間を目安とした。耳鳴のピッチ マッチ検査，ラウドネスバランス検査は毎月測定し た。耳鳴の自覚的評価法として1993年耳鳴研究会が 作成した標準耳鳴検査法 ${ }^{9)}$ の中の問診項目から耳鳴の 大きさ，耳鳴の持続，耳鳴の気になり方についてそ れぞれ毎日 5 段階で評価してもらい，1 カ月ごとに 平均化した值をスコアとして使用した。耳鳴の大き さは, とても小さい；1点, 小さい；2点, 中ぐら い； 3 点，大きい； 4 点，とても大きい； 5 点とし た。耳鳴の持続は，ほとんど鳴らない；1点，たま
に鳴る；2点，鳴ったり止まったり；3 点，たまに 止まる；4点，いつも鳴っている； 5 点とした。耳 鳴の気になり方は，ほとんど気にならない；1点， 仕事中は忘れている；2 点，仕事中ときどき気にな る； 3 点，気になるが仕事は出来る；4 点，気にな つて仕事が手につかない； 5 点とした。また，6力 月治療が経過した時点で, TRT 療法の耳鳴に対する 効果についてアンケートを取った。以下の 4 つの中 から選択してもらった。(1)耳鳴が楽になり，治療を 受けてよかった(有効群), (2)多少は楽になり, 変化 は見られた (やや有効群)，(3)変わりはなかった (不 変群)。(4)かえって悪化した（悪化群）。

なお，統計学的方法は Student $の \mathrm{t}$ 検定を用い, $5 \%$ 以内を有意差とした。

\section{結果}

\section{1 ） TCI の調整について}

TCI 設定条件のうち，ノイズの大きさの推移を図 1 に示す。 2 回目の調整時に $82 \%$ でノイズレベルの 調整変化が見られ，その内レベルが下がった者が50 \%，上がった者が50\%で，平均変動ノイズレベルは $3 \mathrm{~dB}$ であった。全体的には治療開始 $3 \sim 4$ カ月くら いまでは調整レベルが変化する傾向が見られた。ノ イズの種類に関しては，最初の調整時はスピーチノ イズが $55 \%$ ，ピンクノイズが $25 \%$ ，ホワイトノイズ が20\%であったが，最終的に決定したノイズはスピ 一チノイズが $45 \%$ ，ピンクノイズが $25 \%$ ，ホワイト ノイズが $30 \%$ となった(図 2 )。変更を希望した者は 5 名 $(25 \%)$ で，そのうち 4 名が変更後に耳鳴の改 


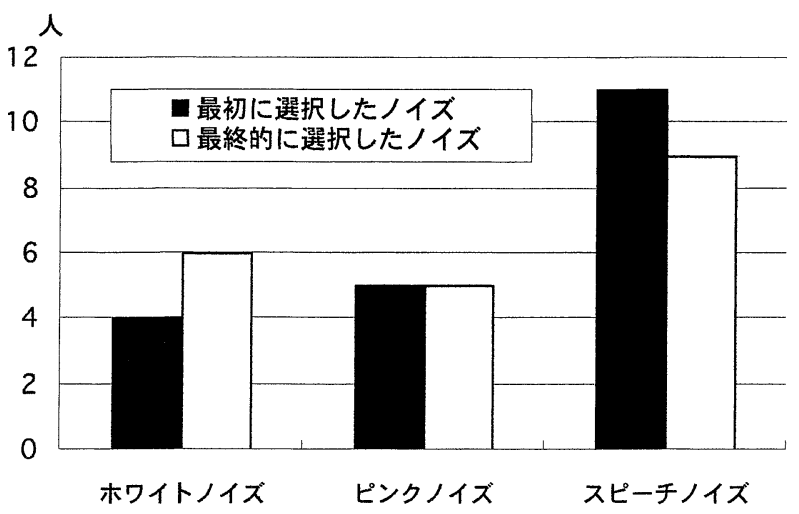

図 2 選択した TCIノイズの変化

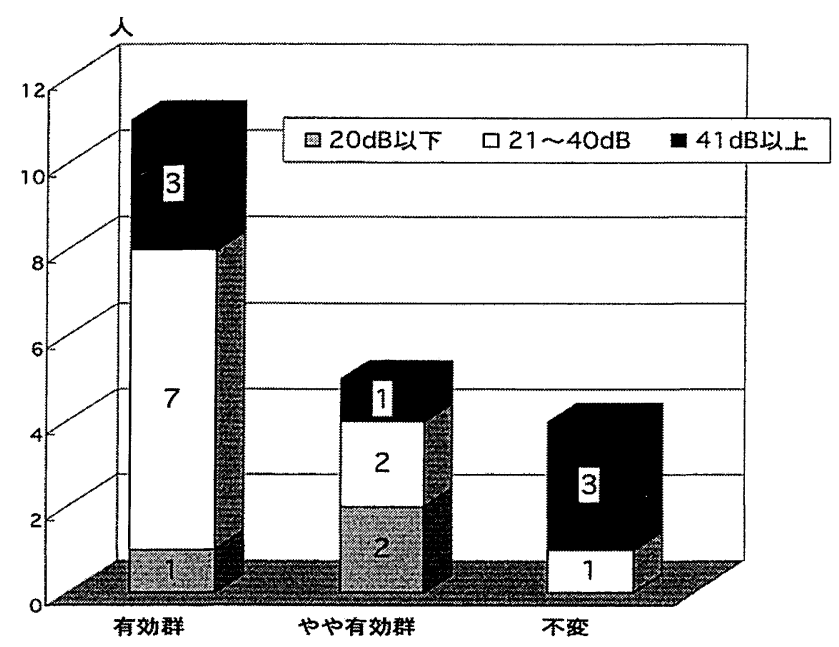

図 3 自覚的有効性評価と難聴の程度

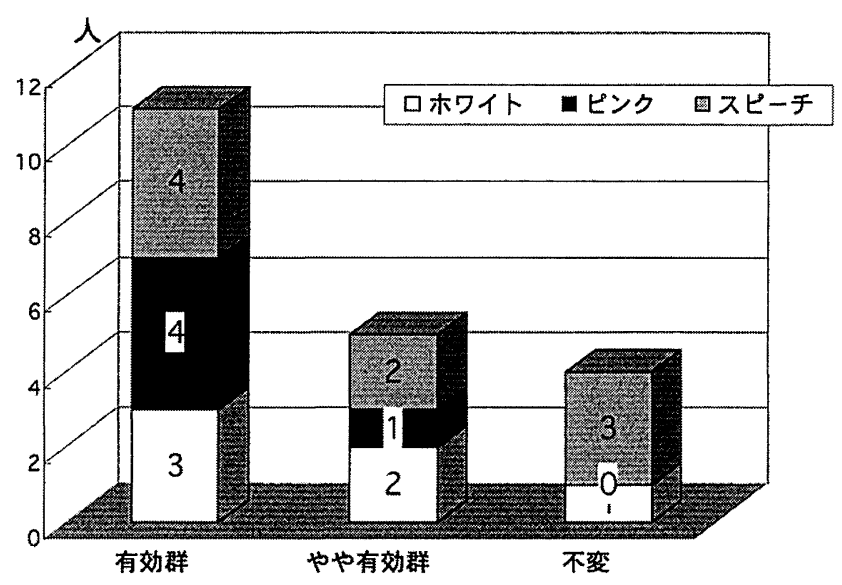

図 4 自覚的有効性評価と選択したノイズ

善を認めた。

2）自覚的評価による治療効果について

6 力月の時点における TRT 療法の有効性に関して の自覚的評価（図 3，4）では有効群が55\%, やや 有効群が $25 \%$, 不変群が $20 \%$, 悪化群は $0 \%$ であり, 有効群とやや有効群を含めた有効率は $80 \%$ となった。 自覚的有効性評価と難聴の程度 (平均聴力レベルで $20 \mathrm{~dB}$ 以下，21〜40dB，41dB 以上の 3 群に分けた） （図 3 ）・使用したノイズの種類（図 4 ）との関連を 検討した。平均聴力レベルが21〜 40dB の群において 有効群が70\%を占め, 他の群と比較して有意に高い 効果が認められた。しかし，使用したノイズによる 有効性の違いは見られなかった。

3 ) 自覚的評価による耳鳴スコア

自覚的耳鳴の大きさの変化を有効群, やや有効群, 不変群で比較すると(図 5 ), TRT 療法開始 3 力月以

降から有効群で有意な耳鳴の大きさの改善が認めら れた。耳鳴の気になり方については，有効群におい て TRT 療法開始 4 力月以降でスコアの低下が見られ た(図 6 )。ただし，統計学的に有意差がみられたの は 4 力月時のみであった。耳鳴の持続時間は，大き さや気になり方と違いいずれの群においてもほとん ど変化は見られなかった（図 7 )。

他覚的評価としての耳鳴のラウドネスバランス検 查では, 有効群においても耳鳴ラウドネスの改善は 認められなかった。

\section{考察}

1996年以降, TRT 療法の報告がイギリス・米国 · ドイッ・ポーランドを始めとして広く見られるよう になり，70９0\%の有効率がこれまでに報告されて いる ${ }^{2 \sim 7)}$ 。TRT 療法はカウンセリングと TCI 装置によ 


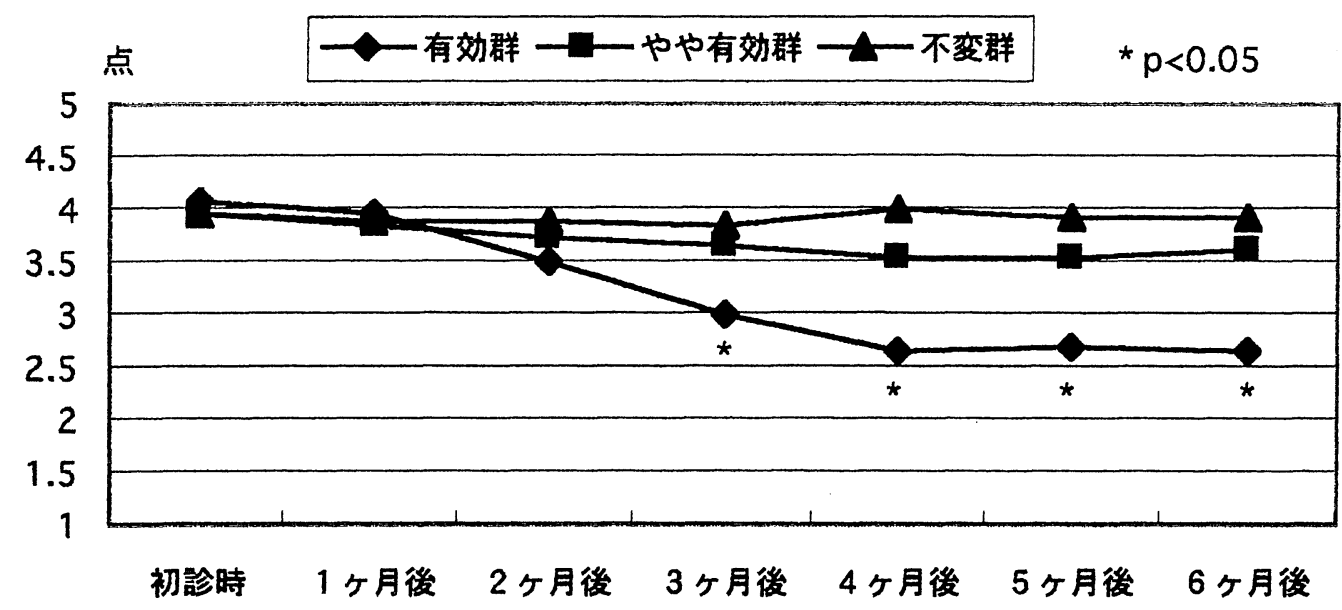

図 5 自覚的耳鳴の大きさスコアの変化

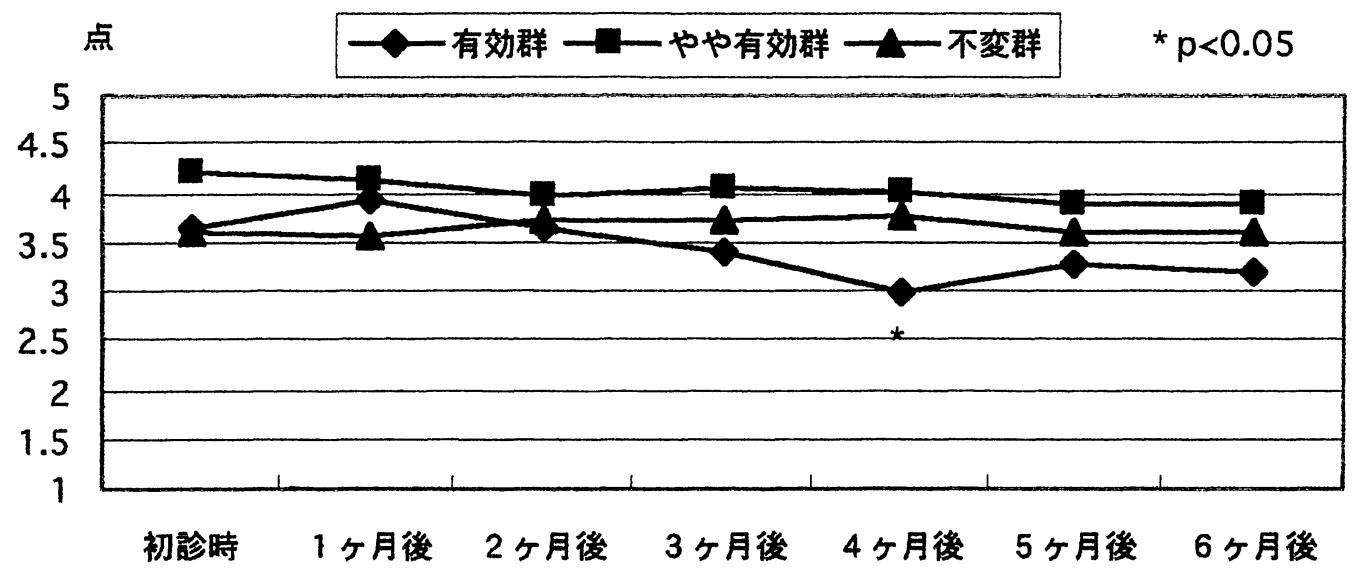

図 6 自覚的耳鳴の気になり方スコアの変化

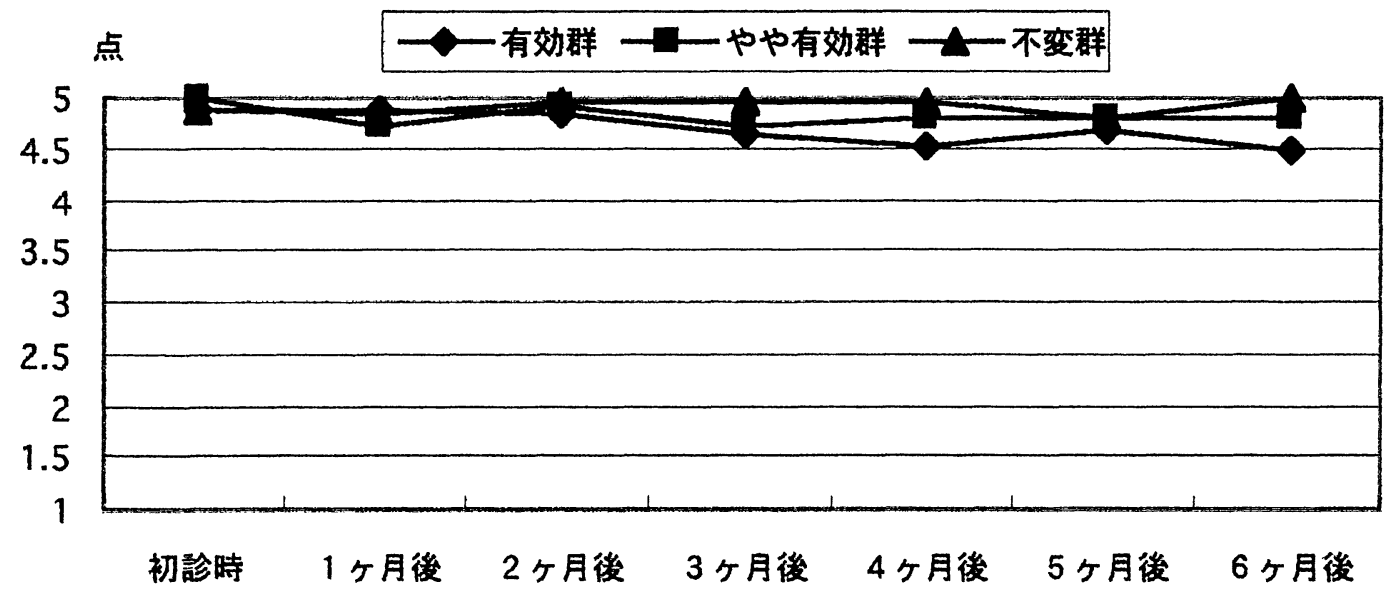

図 7 自覚的耳鳴の持続時間スコアの変化

る音治療で，耳鳴に慣れさせる事が目的のため，効 果の評価方法は耳鳴に対する気になり方・苦痛度な どの自覚的評価によるものが多い。今回我々は異な る 2 つの自覚的評価法で TRT 療法の効果を検討した。
すなわち，6 力月後に全体的な TRT 療法の有効性に ついて 4 段階で答えてもらう方法と連日耳鳴の大き さ・気になり方・持続についてスコアを記録しても らい，1 カ月ごとの平均值を出す方法により，比較 
検討した。前者の有効性の評価では, 有効群とやや 有効群を合わせた有効率は $80 \%$ であった。しかし， 脱落例を含むと有効率は $61.5 \%$ となる。たがって, これまでの報告とほぼ同様な有効性が得られたと思 われる。Bartnik らの報告 ${ }^{10)}$ では難聴の自覚がない耳 鳴の有効率は70\%であったのに対し，難聴の自覚が

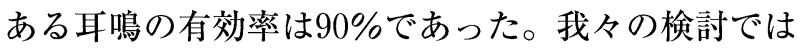
平均聴力レベルが21〜 40dB の群において有効群が 7 0\%を占め, また有効群の $64 \% か ゙ 21 〜 40 \mathrm{~dB}$ 群であり, $20 \mathrm{~dB}$ 以下 $\cdot 41 \mathrm{~dB}$ 以上の群と比較して有効率が高い 傾向が認められた。

耳鳴の自覚的評価の欠点として, 耳鳴は患者自身 の体調や，天候などによって左右されたり，病院を 受診し, 医師と話をするということで満足感を得て, 良くなったりすることがあり，一時的な判断では正 しく評価できない可能性を考慮し, 今回我々は連日 耳鳴の大きさ・気になり方・持続についてのスコア を 1 カ月ごとに平均化する方法を取って, TRT 療法 の効果に対し 6 力月後の自覚的有効性と比較検討を 加えた。自覚的耳鳴の大きさと気になり方は 6 力月 の時点において不変群に比べ,やや有効群, 有効群 の順でよりスコアの改善が認められた。しかし，耳 鳴の持続時間に関して各群間では差は見られなかっ た。Jastreboff は耳鳴の気になり方と持続時間が治療 開始 6 力月後約 $30 \%$ 低下したと報告 ${ }^{4}$ している。我々 の検討では耳鳴の大きさは有効群で $39 \%$, やや有効 群で $9 \%$ の低下が，また耳鳴の気になり方は有効群 で13\%，やや有効群で $9 \%$ の低下が見られた。TRT の効果は, 耳鳴のする時間は以前とは変わらないも のの, その大きさや, 耳鳴のために不快に思う程度 が軽くなり, 全体的評価として耳鳴が良くなったと 判断していることが示唆された。

TRT で使用されるノイズは, 馴染みやすく聞きや すいということで，ホワイトノイズを用いることが 多(4) が, 今回我々は治療に用いるノイズを限定せず, 患者自身に選択してもらった所，スピーチノイズを 選択する割合が多かった。TCI 1 回目の調整時は, ほ とんどの者が聞き慣れないノイズに戸惑いを示した が，最終的に選択したノイズはホワイトノイズがや や増加したものの, スピーチノイズが最も多かった。 今回の検討では $23 \%$ （6名）に6 力月間治療が継続 できなかった脱落例が存在したが，10～27\%の脱落
例が他の報告 $4,8,11)$ でもみられている。 2 週間から 3 カ月で治療を断念した 6 名の理由は,「治療効果がな い」, 「装用が煩わしく補聴器をつけているようで見 た目に良くない」，「そこまで困っていない」，「かえ って音が響き不快だった」，「高度の視力障害のため 器具の扱いが困難だった」であった。TRT 療法の効 果は $3 \sim 6$ 力月で見られてくるとの報告 ${ }^{5,6)}$ があるが, 我々の検討では耳鳴の大きさは有効群, やや有効群 とも治療開始 3 力月から, 耳鳴の気になり方は有効 群で治療開始 4 カ月から改善が見られ始めた。統計 学的には耳鳴の大きさで有効群の治療開始 $3 \sim 6$ 力 月, 耳鳴の気になり方では有効群の治療開始 4 力月 に有意差が認められた。最初は器具の扱いや耳に装 着する煩わしさをほとんどの人が感じるため, はじ めの 1 力月間は, むしろ治療自体に慣れるための期

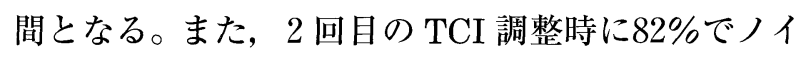
ズレベルの調整変化が見られた事もあり, 患者には 効果はすぐに現れるわけではないことを十分説明し ておくことが重要と思われる。

TRT の適応は聴力閾值が TCI の最大ボリュームを 超えない中等度以内の難聴 (約60dB 以内) で, 治療 の内容を理解可能な耳鳴患者としている。聴覚過敏 の耳鳴には特に有効とされている ${ }^{11}$ 。耳鳴の新しい治 療として TRT が我が国でも試みられるようになって きたが，まだ治療の進め方や適応については明確に なっていない。今後より多くの症例の長期的な観察 と様々な角度からの検証を行い, TRT 療法の適応と 治療法に関してさらに検討していく必要がある。

\section{ま と め}

3 力月以上内服その他の耳鳴に対する治療を行っ ても改善しなかった耳鳴患者26名に対し TRT 療法を 試み， 6 力月以上治療が継続できた 20 例を対象に, TCI の治療音と音量の変化と自覚的評価による治療 効果について検討した。

1. TCIのノイズの種類は, スピーチノイズを選 択する者が多かった。 5 名がノイズの種類の変更を 希望した。2 回目の調整で，82\%でノイズレベルの 調整変更が見られた。

2. 6 力月時点の TRT 療法の自覚的評価で, 有効 が55\%，やや有効が25\%，不変が20\%，悪化は 0\% で，有効率は $80 \%$ であった。 
3. 自覚的耳鳴の大きさと気になり方は治療開始 後 $3 \sim 4$ カ月で有効群においてスコアの改善が見ら れた。

4. TRT 療法の適応と治療法に関しては今後さら に検討が必要であり，また，適応患者には効果がす ぐに現れるわけではないことを十分説明する事が重 要と思われる。

本論文の要旨は第48回日本聴覚医学会 (2003年) においてロ演した。

\section{Evaluation of Tinnitus Retraining Ther- apy with Regand to Effectiveness and In- strument Fitting}

\author{
Maki Arai, Satoshi Iwasaki, Risako Hayashi, \\ Yasuyuki Hashimoto, Mituyoshi Nagura, Sa- \\ toru Takebayashi, Kunihiro Mizuta, Hiroyuki \\ Mineta \\ Department of Otolaryngology, Hamamatsu \\ Medical School of Medicine
}

Twenty out of 26 patients undergoing tinnitus retraining therapy (TRT) were evaluated after 6 months of treatment. Counseling and sound therapy using a tinnitus contror instrument (TCI) were used. Fitting of the TCI was performed every month. Fifty-five percent of the patients selected speech noise, and the noise level was varied for 3 month period.

An interview regarding the effectiveness of TRT indicated that the treatment was effective in 55\% of the patients, slightly effective in $25 \%$, and not effective in $20 \%$. None of the patients, conditions were aggravaled by the treatment. An improvement rate of $80 \%$ was obtained in the group that received the full treatment; the overall improvement rate was $61.5 \%$. A reduction in the average scores for awareness of tinnitus loudness and the level of annoyance occurred after 3 to 4 months of treatment ; these reductions were correlated with the effectiveness of TRT.

TRT must be performed for 3 to 4 months to prop- erly fit the TCI and assess the effectiveness of TRT in patients with tinnitus.

\section{参考文献}

1) Jastreboff PJ : Phantom auditory perception (tinnitus) : mechanisms of generation and perception. Neurosci Res 8:221-254, 1990

2 ) Sheldrake JB, Jastreboff PJ, Hazell JWP, et al : Perspectives for total elimination of tinnitus perception. Proceedings of the Fifth International Tinnitus seminar. Porland ; American Tinnitus Association 531-536, 1995

3 ) Henry JL, Wilson PH : The psychological management of tinnitus : comparison of a combined congnitive-educational program, education alone and a waiting-list control. Int Tinnitus J $2:$ 9-20, 1996

4) Jastreboff PJ, Gray WC, Gold SL : Neurophysiological approach to tinnitus patients. Am J Otol 17 : 236-240, 1996

5 ) McKinney CJ, Hazell JWP, Graham RL : An evaluation of the TRT method Proceedings of the Sixth International Tinnitus seminar. UK ; British Society of Audiology, 99-105, 1999

6 ) Kroener-Herwig B, Biesinger E, Gerhards F, et al : retraining therapy for chronic tinnitus: a critical analysis of its status. Scand Audiol 29: 67-78, 2000

7 ) Skarzynski H, Rogowski M, Bartnik G, et al : organization of tinnitus management in Poland. Acta Otolaryngol 120 : 225-226, 2000

8 ）松田太志, 関谷芳正, 高橋真理子 - 他 : Tinnitus Retraining Therapyによる耳鳴治療（その 2 )。 Audiology Japan 45 : 671-679, 2002

9 )「標準耳鳴検查法 1993」：耳鳴研究会, 1993

10) Bartnik G, Fabijanska A, Rogowski M : Effects of tinnitus retraining therapy (TRT) for patients with tinnitus and subjective hearing loss versus tinnitus only. Scand Audiol suppl 52 : 206-208, 2001

11) Jastreboff PJ, Jastreboff MM : Tinnitus retraining therapy(TRT) as a method for treat- 
ment of tinnitus and hyperacusis patients. J Am

Acad Audiol 11 : 162-177, 2000

（原稿受付 平成16.5.25）

別冊請求先 $=431-3192$ 静岡県浜松市半田山1-201

浜松医科大学耳鼻咽喉科

岩崎聡

\section{Reprint request :}

Satori Iwasaki

Department of Otolarynglogy, Hamamatsu University School of Medicine, 1-20-1, Handayama, Hamamatsu city, 431-3192, Japan 